\title{
Models of rhetorical relations in Russian blogging as an indicator of interlocutors' information behavior
}

\author{
Victor M. Shaklein ${ }^{1}$, Inna V. Kovtunenko \\ ${ }^{1}$ Peoples' Friendship University of Russia (RUDN University), \\ 6 Miklukho-Maklaya St, Moscow, 117198, Russian Federation \\ ${ }^{2}$ Don State Technical University, \\ 1 Ploshchad' Gagarina, Rostov-on-Don, 344000, Russian Federation
}

$\checkmark$ vmshaklein@bk.ru

\begin{abstract}
Russian blog texts are characterized by the fact that the respondent expresses opinions in order to convince the author of the effectiveness of certain ideas that cover his/her private life and professional activities. The respondent presents arguments in favor of his/her opinion, introduces the rationale for it, and at the same time indicates that the point of view previously expressed by the blogger is also relevant in the contextual situation under discussion. Rhetorical relations project conflict-free development of easy communication. As a result, the points of view put forward by the blogger and the respondent complement each other. It turns out that the same situation potentially generates both positive and negative emotions, and this is emphasized in the virtual communication based on the implementation of the phatic function of language. Rhetorical relations within the blog text help to combine different epistemic positions expressed by the interlocutors. In this regard, an urgent problem of linguistic research of Russian blog texts is to determine whether the interlocutors who exchange opinions and assessments form integral models of dialogic communication, based on which means of linking the stimulating and reacting messages are connected. This problem has not yet received proper empirical analysis in Russian studies and general language theory, although its solution, as we believe, contains significant implications for detailing the pragmatic specifics of blog communication. The aim of the study is to implement a structural and pragmatic analysis of rhetorical relations in blog texts, which involves identifying the dominant markers of these relations, their basic model and its variants. The goal stated in the article is realized through the following research methods: (1) the method of observation and interpretation of blogging while analyzing the peculiarities of the linguistic means of implementing connectivity; (2) descriptive-analytical (contextual) method-direct analysis of blog text fragments as a linear sequence; (3) a method for modeling rhetorical cause-and-effect relationships between segments of a single replica and at the level of integral dialogic unity in the blog text. It is concluded that rhetorical relations fix national and cultural stereotypes, which, in turn, determine the material and ideal scope of the degree of relevance of the addressee's evaluation activity. When implementing such speech actions, the interlocutors take into rigid consideration not only the frequent and dominant cultural scripts of dialogic axiological performance, but also the relevant stereotypes of such activities that are set by the language system. The rhetorical relations between stimulating and reacting messages in the context of computer-mediated communication generate facilitate the processes of decoding the informative and emotional content of the jointly generated text and its implications.
\end{abstract}

Keywords: context of Russian computer-mediated communication, Russian blog text, rhetorical relations, interlocutor's point of view, discursive step, interactivity 
Article history: received 12.10.2020; accepted 22.12.2020.

For citation: Shaklein, V.M., \& Kovtunenko, I.V. (2021). Models of rhetorical relations in Russian blogging as an indicator of interlocutors' information behavior. Russian Language Studies, 19(2), 167-179. http://dx.doi.org/10.22363/2618-8163-2021-19-2-167-179

\section{Introduction}

In contemporary pragmatic research, there is an increased interest in the empirically proven fact that interpersonal interaction in the process of real language functioning cannot be reduced to an elementary exchange of stimulus and reaction (Gavrilova, 2015: 89; Kudryashov, Kalashnikova, 2015: 43; Akay et al., 2017: 12). It is recognized that the formats of utterance production and perception are determined by the current interaction context, the speaker and his/her interlocutor's communicative roles, characteristic of a certain genre of communication (Gurochkina, 2015: 553; Kovtunenko et al., 2021: 81). The pragmatic analysis of the prerequisites and implementation of active participation in interpersonal interaction takes into account the specific configuration of the addressee and his/her respondent's communicative roles in relation to the act of communication, which is understood as the construction and interpretation of some semantic content encoded by language means in a coherent message, text or utterance (Anufrieva, 2016: 83).

In our research, we attempt to explain the pragmatic specifics of the functioning of the rhetorical relations in computer-mediated communication, which trace the features of this type of communication in the aspect of contrasting the language oral and written forms. The solution of this problem is closely related to the question of technical determinism. The verbal behavior of internet users is interpreted as a consequence of the physical conditions of the technological environment production and the perception, in which the language functioning is predetermined by the advantages and limitations provided by this environment. The pragmatic nature of computer-mediated communication determines the availability of language for metalinguistic reflection to a greater extent than in oral interpersonal communication (Volodina, Kovalchuk, 2019; Myers, 2010; Kirillov, 2017).

The blog provides the implementation of a discourse controlled by the author, his/her personal preferences and needs. In this regard, the preferences and needs that the blog meets are more individual than in other genres of the public expression of thoughts and emotions. By initiating messages, the blogger projects the content and emotional nature of readers' reactions, their stylistic design (Ibraeva, 2018: 334; Kalashnikova, 2017: 45; Schipichina, 2010: 21). The jointly generated text is implemented through the relationship between the blogger and respondents, which is implicit in the content of the resulting text. This text is characterized by the mobility and variability of joint goals (as well as stylistics and content).

As part of our research, the problem of constructing the interactive essence of blog texts is solved by identifying and analyzing various markers of interactivity, determining whether the interlocutor reacts to the blogger's stimulating message or another respondent's response. In this regard, our research focuses on the problem of recreating interactivity in the response speech moves that manifest agreement or disagreement with the blogger or respondent's point of view. 
Stimulating and responsive dialogic steps taken by the blogger and respondents potentially set the context for similar actions of subsequent interlocutors, and create the need for a relevant response to already voiced judgments (Schmidt, 2007: 17). In this case, we are guided by the generally accepted theoretical position, according to which any interaction between communication participants can be interpreted as the implementation of contextual restrictions on the nature of subsequent illocutionary actions; entering into a dialogue, the interlocutors, in fact, determine the stimuli and reactions, activating the addressee factor.

The interactive potential of rhetorical relations between the blogger and respondents' stimulating and reacting messages, discursive steps aimed at expressing agreement/disagreement with the interlocutor's opinion are analyzed in the research through the hypothesis that interpersonal interaction in the blogosphere is realized in terms of rhetorical relations between stimulating and reacting messages, expressing agreement/disagreement with the opinion of the interlocutor. The participants' discursive opposition in the computer-mediated communication is embodied in specific models of rhetorical relations between stimulus and response, discursive steps that link the jointly generated text into a single structural and semantic whole.

The blogger has a priority right of control over the form and content of the text, posed together with respondents, a respondent in defending this right, shall enter into a confrontation with the blogger (Mann, Matthiessen, Thompson, 1992; Borisova, Semelet, 2017). The rhetorical relations between different segments of the joint text, commenting on the activities of bloggers and respondents are predetermined by the linguistic and cultural practice of interpersonal interaction, established in the computer-mediated communication.

\section{The aim of the research}

The object of the research is the models of blog texts generating, which are stable relations of stimuli and reactions aimed at coherent development of a joint speech work.

The aim of the research is to identify the pragmatic potential of rhetorical models for generating coherent blog texts, which is predetermined by the interlocutors' informational behavior.

\section{Methods and materials}

The material of this research is blog texts in Russian. In this research, the blog text is defined not only as a structural and semantic sequence of stimulating and reacting messages, but also as a pragmatic and linguocultural configuration of the language, which is aimed at maintaining a phatic contact between participants in virtual communication through the manifestation of certain meanings, a specific structural organization of the aggregate text.

Blog texts are a pragmatic and linguocultural system that is generated taking into account the potential of a particular language system (Nayar, 2010). In this regard, we consider the blog text as not consisting of separate segments, but implemented and encoded in the semantic and structural organization of these segments. This text communicates actual meanings selected from a potential semantic set that are intended to be transmitted to the author or respondent. In other 
words, the blog text is defined in our research as an updated structure that conveys certain semantics, including emotive ones.

The purpose and solution of the tasks outlined in the study require the following basic research methods to be used. These methods are relevant for the pragmatic and linguocultural analysis of the problems of text generation in the blogosphere:

- contextual method that determines the typology of rhetorical relations between blog text segments, discursive steps implemented by bloggers and respondents who interact with each other;

- a method of functional analysis, which is the basis for distinguishing the dictum and modus meaning of stimulating and reacting messages that form a coherent blog text, and identifying the pragmatic load of the interlocutors' discursive steps as a metafunction of language tools;

- modeling method:

- rhetorical relations formed between contacting and distantly located segments of blog text that are marked by certain language means or are implicit;

- the nature of interlocutors' joining discursive steps, which are based on certain intentions related to establishing and maintaining the phatic contact with the partner.

\section{Results}

This study highlights the problems associated with clarifying the complex architectonics of interpersonal communication in the blog text, which is aimed at implementing certain extralinguistic strategies and, in this regard, using a number of rhetorical structures. Based on the theory of rhetorical structures developed by Mann and Thompson, we investigated such problems as:

- types of rhetorical relations that are relevant when forming the blog text holistic nature;

- identifying the blog text minimum fragment, in the context of which a certain type of rhetorical relations is established;

- identifying the pragmatic and cross-cultural specifics of a blog text fragment that implements rhetorical relationships between different segments.

\section{Discussion}

The blog text is mainly focused on implementing non-linguistic tasks (Kalashnikova et al., 2017: 163), and therefore it is a hierarchically structured discursive phenomenon that is optimal for research in the aspect of the theory outlined above. In fact, we use the model of rhetorical structure to identify the integral structure of the blog text, which is jointly generated by the interlocutors' dialogic steps. So, according to our observations, the basis for generating respondent's responsive messages is not so much the need to solve some extralinguistic problems, but the desire to implement the corresponding rhetorical goals. This clearly shows the cross-cultural specificity of such messages.

Cf., the blog text fragment in Russian (1), in which the responding interlocutor's replica is more the argumentative justification of the sender's stimula ting message, rather than a way to solve non-linguistic problems that are relevant to the interlocutors at the moment (for convenience, here and further, stimulating and responding messages are designed as the dialogical replicas): 
(1) “- (X) Taker - ne nastojashhij skorer, razygryvat' klassicheskie broskovye kombinacii emu tjazhelo...

- (X') Potomu chto umet' perestraivat' svoju igru v takom vozraste - jeto pokazatel' intellekta...";

“- (X) Tucker is not a real scorer, it's hard for him to play classic throwing combinations...

- (X') Because being able to rebuild your game at that age is an indicator of intelligence..."

In the initiating message $(\mathrm{X})$, the blogger makes a value judgment that it is difficult for a well-known basketball player to play classic throwing combinations. Reacting, the respondent in the message ( $\left.X^{\prime}\right)$ does not solve any extralinguistic problems, but details the original judgment and presents strong arguments for its justification. In this case, the responding message is marked with the subordinate conjunction potomu chto/because, which is used in the position of the utterance absolute beginning. As a result, a rhetorical relationship of justification is formed between the stimulating and reacting messages, and the messages themselves form a complete text fragment (cf.: ...razygryvat' klassicheskie... kombinacii emu tjazhelo, potomu chto umet' perestraivat' svoju igru v jetom vozraste - pokazatel' intellekta/...it is difficult for him to play classic... combinations, because being able to rebuild his game at this age is an indicator of intelligence). The respondent reacts to the state of affairs that is covered by the blogger, details this state of affairs with new facts, transforming both messages into a single coherent sequence.

The problem of applying the rhetorical structure theory to the study of blog texts has not yet been fully developed in the language theory. If we mark the rhetorical structure in the context of interlocutors' individual coherent dialogical moves, then distantly located structures are outside the scope of direct consideration. There is also the problem of defining dialogical activity specific to the blogger and the respondent, and reflecting this activity in messages that take a strong semantic position and only maintain a physical contact between the interlocutors.

In order to detail the pragmatic and cross-cultural specifics of the rhetorical relationships between the various components of the blog text, we analyze individual statements as the blog text basic units. In turn, these statements are segmented into separate syntactic syntagmas, which are characterized by some propositional content. As our analysis has shown, the blogger and respondent's dialogical moves often form a complete statement, the coherence of which is provided by one or another compositional or subordinate conjunction, introductory word or adverb. Such utterances are segmented into two parts (often coinciding with the stimulating and reacting message), the connecting medium and the character of the rhetorical relations that it marks are established.

The computer-mediated communication, recorded in the blog text, is implemented in the blogger and respondent's dialogic steps, each of which has the unique system of values and intentions, which are systematically reflected in a joint attempt to maintain interpersonal contact and simultaneously solve an extralinguistic problem. We have identified a number of respondent's rhetorical strategies

${ }^{1}$ Blog London Eye. 2020. (In Russ.) Retrieved February 2, 2021, from https://www.sports.ru/ tribuna/blogs/londoneye/ 
aimed at establishing and maintaining cooperation, synchronizing views and semantic positions that are voiced in the blog text.

These strategies include a detailed answer to the question, expressing agreement with the blogger's opinion, and recognizing the effectiveness of the semantic position initiated by him/her. Thus, in the text fragment (2), the reacting message $\left(X^{\prime}\right)$ provides the motivational basis for the initiating message $(X)$. At the same time, it can be said that the respondent would not have made his statement without a proper incentive (the question statement Jeto dejstvitel'no tak?/Is this really so?). Cf::

(2) “- (X) (a) 'Spers'-2019 vpolne mogut opjat' vyigrat' obydennye dlja sebja 45-50 igr $i$ vyjti v plej-off. No za 20 let dominirovanija oni priuchili nas sovsem $k$ drugomu, pojetomu sezon 2018/19 v ispolnenii 'San-Antonio' oshhushhaetsja po-drugomu. Kak budto jeti 'Spers' - uzhe ne te, $k$ kotorym my privykli. (b) Jeto dejstvitel'no tak?

- (1-X') (c) Da normal'no vsjo. (d) Trener rabotaet s tem materialom, chto est' i rabotaet neploho. Za Kavaja tozhe poluchili pochti maksimum, chto mogli. Vernjotsja Mjurrej, Uokera vklejat - i budet poveselee. Derzhat'sja na stabil'no vysokom urovne tak dolgo, pri jetom, ne vzryvaja sostav, nikto v NBA ne mog. Zhal', s Kavaem tak vyshlo. Inache vsjo moglo byt' gorazdo luchshe.

- (2-X') (e) Vsjo kogda-nibud' vsjo. (f) I jeto normal'no";

“- (X) (a) 'Spurs'-2019 may well again win their usual 45-50 games and reach the playoffs. But over 20 years of dominance, they have taught us something completely different, so the 2018/19 season in the performance of San Antonio feels different. As if these spurs aren't the ones we're used to. (b) Is this really true?

- (1-X') (c) Yes, everything is fine. (d) the Trainer works with the material that is available and works well. For Kawai, too, we got almost the maximum we could. Murray will return, Walker will be pasted in - and it will be more fun. No one in the NBA could stay at a consistently high level for so long without blowing up the roster. Otherwise, it could have been much better.

- (2-X') (e) All someday all. (f) And this is normal"'2.

If we mark the rhetorical relations of motivation between the dialogical steps of the three interlocutors $(X),\left(1-X^{\prime}\right)$ and $\left(2-X^{\prime}\right)$, then we do not cover the rhetorical structure of the entire text fragment, since the corresponding segments that connect in a semantic sense are not directly adjacent. We also do not take into account the constructive rhetorical relations that are formed between the messages (1-X') and (2-X'). It seems to be more optimal to mark the questionand-answer rhetorical relations between segments (b), (c) and (e) and motivational rhetorical relations between segments (a), (d) and (f). In other words, the segmentation of the statements belonging to the blogger and two respondents makes it possible to present in more detail the rhetorical structure of the analyzed fragment of the blog text. In the process of co-generating the blog text, participants in computer-mediated communication simultaneously pursue several rhetorical strategies.

Directly adjacent segments of blog texts form various rhetorical relationships, which are systematized in Table.

${ }^{2}$ Blog London Eye. 2020. (In Russ.) Retrieved February 2, 2021, from https://www.sports.ru/ tribuna/blogs/londoneye/ 
We investigated the problems associated with annotating the virtual blog text in terms of the rhetorical structures generated in this type of text. First of all, our attention is focused on the question of whether the problems presented above are a relevant object of research when considering the argumentative potential of the blogger and respondent's dialogical steps in the process of unfolding texts that reflect the cross-cultural specifics of the current computer-mediated communication. The theory of rhetorical structures is interpreted in our research as a descriptive concept of hierarchical discursive structures, based on which functional relationships between blog text segments are identified. The origin of these structures is based on the participants' initial intentions, which determine the holistic nature of the jointly generated blog text.

Types of rhetorical relations between blog text adjacent segments

\begin{tabular}{ccc}
\hline Argumentative statements & Subtypes of detailing relations & Perlocutive effects \\
\hline Question - answer & $\begin{array}{c}\text { Clarifying a certain state of affairs } \\
\text { voiced by the blogger }\end{array}$ & $\begin{array}{c}\text { Presenting the blogger's opinion } \\
\text { in a comic light }\end{array}$ \\
\hline $\begin{array}{c}\text { Expressing an opinion - recognizing } \\
\text { the effectiveness of the opinion }\end{array}$ & Motivating the blogger's position & $\begin{array}{c}\text { Finding the common solution } \\
\text { to the problem under discussion }\end{array}$ \\
\hline $\begin{array}{c}\text { Expressing an opinion - refuting } \\
\text { the effectiveness of the opinion }\end{array}$ & $\begin{array}{c}\text { Illustration the blogger's opinion } \\
\text { with specific examples }\end{array}$ & $\begin{array}{c}\text { Multi-aspect describing the state } \\
\text { of affairs under discussion }\end{array}$ \\
\hline
\end{tabular}

In a single segment of the virtual text, a certain type of rhetorical relationship is formed between the stimulus and the response, while the blogger or respondent's separate message reveals its own communicative and pragmatic potential, which serves to solve the general speech problems of the text segment, and, ultimately, the entire communication as a whole.

In particular, the basic function of the blogger's message is to influence the potential respondent emotionally and volitionally in order to get a verbal response from him/her (the incentive function). The dominant functional loading of the respondent's responsive message is primarily explicating the individual response to the impact previously carried out by the blogger (the reactive function) based on value judgments.

From the respondent's point of view, the process of relevant decoding of the blogger's original message is important, which, in turn, involves taking into account the entire set of semantic and pragmatic components of the message, which are expressed with varying degrees of clarity. The process of decoding speech messages and the processes of "extracting" implicatures of meaning is, among other things, linguocultural in nature. In the virtual communication the participants' pragmatic attitude to each other's messages as an extralinguistic factor is manifested in the evaluation of other individual's speech forms. These forms are peculiar moments of regulating the communicative process, which are reflected in the rhetorical structure of the jointly generated virtual text.

The processes of understanding involve decoding the deep cognitive information of the received message. Extracting the meaningful segments of a stimulating message based on frames is determined by pragmatic factors, since it presupposes considering the respondent's factor, the peculiarities of his/her cognitive, linguistic, social and cultural spheres. We define a frame as a relevant combination of 
informative structures that contains the personal knowledge of the interlocutor, revealing the features of his/her individual communicative experience, emotional and sensory attitudes, and expectations from the current communication.

Messages that form a segment of the open virtual text are not only interdependent, but also interrelated. This relationship is defined in our study as a coordinative one. The coordination links are formed if the response to the communicative intentions expressed in the stimulating message is recorded in the reacting message. We consider the semantic identity of the stimulus and response propositional structures as the basic form of making this connection public. The coordinative relationships determine such basic characteristics of the virtual text segment as communicative purpose and structural integrity. In other words, these connections combine pragmatic and structural-semantic cohesion.

The scientific novelty and actuality of researching presupposes the following basic aspects systematically eveloped in the course of the pragmatic analysis of the means and methods of maintaining the coherent nature of the Russianlanguage blog text.

First, the entire set of message chains that form the blog text is presented in the form of certain rhetorical relationships, in which each message is an agreement/disagreement with the opinion of the interlocutor, a statement or a denial. In the blog text rhetorical structure, the microtheme being discussed is represented in terms of various combinations of affirmation and negation in stimulating and reacting messages (for example, negation-affirmation; negation-negationnegation, etc.). Such combinations embody the nature of the relationship of interlocutors' agreement and disagreement with each other's opinions.

Secondly, it is proved that the responsive comments form a virtual space in which respondents are more focused on providing a response to the blogger than on clarifying and detailing the message initiated by another respondent. Respondents tend to support the issues that were originally covered by the blogger in a stimulating message, rather than offering new issues for discussion. A shift to a new topic of communication is outlined in the blog text in connection with an informative exchange between the interlocutors, in which disagreement was initiated with the point of view expressed by one of the partners.

Third, the stimulating message format that reflects the dominant informative content in the virtual text, and the format of responsive messages over which the blogger gets communicative control, are interpreted as constructive factors that determine the type of discursive steps of participants in computer-mediated communication, maintaining its coherent nature, including in terms of detailing the issues originally proposed by the blogger for subsequent discussion. When initiating computer-mediated communication, bloggers respond to respondents' messages with varying degrees of discursive activity, guided by their dominant role in the unfolding of the text or by the informative sufficiency of judgments put forward by their interlocutors. Source info blogger interpreted by respondents as the dominant incentive for the development of communication, however, they express their reactions to each others posts as the result of certain discursive steps, prevalent of which are disagreeing with the interlocutor, critical opinion in relation to the semantic positions, express them, and please provide the relevant information. 
Fourth, the interdependence between the implementation of conversational control over the topic of discussion and voicing disagreement with the interlocutor's position, presenting criticism of this position and searching for up-to-date information about the discussed event is revealed. The study showed that in the format of modern blog texts, the exercise of control over the topic of the current discussion is predetermined by a certain range of discursive steps. In the research plan, the analysis of the frequency of response of bloggers and respondents to each other's messages is based on the typology of discursive steps relevant for this type of communication. Analysis of reactive messages in the process of commenting on the activities of participants in virtual communication has shown that the discursive step of disagreement with the opinion of the interlocutor is a predictable linguistic and cultural practice in the course of coherent unfolding of the blog text.

The theoretical significance of the research is associated with the fact that the results make a certain contribution to the pragmatic theory of language functioning in the computer-mediated communication, the study of the phenomenon of the interlocutor's discursive opposition when expressing agreement/disagreement in this type of communication. Factors such as the ability to act as the addressee of a message, interactive exchange of opinions, and control over the topic of discussion determine the format of respondents' reactions and current models of interaction between participants in the computer-mediated communication.

The practical perspective of researching is predetermined by the prospect of using its main results for further theoretical detailing of the problem of coherent representation of texts in computer-mediated communication, for determining the pragmatic and linguistic-cultural patterns of connecting stimulating and reacting messages in asynchronous interactive forms of communication.

The theoretical conclusions obtained in the study can be applied in University teaching of contemporary Russian language, stylistics of genres and registers of the virtual communication, special courses on the problems of the language tool contextual use in a wide variety of communicative situations and its linguistic and cultural variables such as the physical space and cultural background of communication, interlocutors' discursive roles, situationally predetermined grammatical means of influence.

The use of analysis techniques developed in the theory of rhetorical structures is constructive in identifying the blogger's communicative skills to maintain the attention of multiple respondents to their message, to organize the subsequent unfolding of the blog text due to reader's reactions. The analysis of the blog text is aimed at identifying the specifics of the interpretation of this text by the addressees, which, in turn, is one of the current problems of general and private linguistics of the text and discourse.

The researcher acts as a third-party observer of the current results of interaction between participants in the computer-mediated communication, takes into account the direct contexts of the virtual communication in order to record how the author and multiple respondents:

- create blog text together and asynchronously;

- incorporate the messages of the partners in the interaction in their own discursive work;

- activate certain types of rhetorical relations between the segments of the virtual text. 
In line with the stated problems, the text of a Russian-language blog can be interpreted as a structural and semantic corpus of asynchronous texts, a discursive process predetermined by the author and multiple respondents. Each message is analyzed as an autonomous text segment, a kind of reaction to the social and linguistic-cultural contexts of virtual interaction, and a relevant contribution to the progressive unfolding of a coherent blog text. This perspective of pragmatic research harmoniously combines interactive and textual approaches to the studied language phenomena.

\section{Conclusion}

Blog texts are rhetorical, since they are formed in the process of discursive interaction between the author and readers, which is reflected in the communicative goals of a joint text work. Current goals can be considered as incentives for the progressive development of all communication processes, which, therefore, are phenomena of the rhetorical order. In this case, the goal of implementing a specific communication event is "tied" to the typified context. The blog text rhetorical nature reveals the following research implications that are essential for our work:

1) in the process of language functioning, the communicative goals of the jointly generated text are effectively implemented;

2) the genre of the blog text determines the prevalence of specific language structures and pragmatic/linguocultural characteristics in it.

The blog text dynamic nature is reflected in the author's intentions to influence multiple respondents and transform their mental and emotional-volitional states. In this case, the logical thinking of participants in virtual interaction acts as a pragmatic basis for structuring a text. The concept of the blogger and readers' intention to influence each other determines the connection of rhetorical and pragmatic aspects of the discursive phenomena analyzing within the frameworks of the theoretical concept we investigate. In this case, we focus on the architectonics of the speech subject's intentions, which distinguishes and combines the communicative intentions and intentions to have certain effects on the respondent. The stated types of intentions are inherent in different levels of text generation: the addressee first of all initiates communicative intentions in order to ensure the implementation of the intention to produce an effect on the interlocutor.

The pragmatic purpose of rhetorical text organization is to have the intentional effects on respondents. The effects produced by texts on respondents are manifested by the transmission of the event content of the text in the form of narratives, descriptions, interpretations, and statements of information about everyday facts. As a result, the text itself is embedded in the social and linguistic-cultural contexts of interaction between the interlocutors. In terms of theoretical settings, the theory of organization and structuring of texts that we analyze is based on the following postulates, which are the starting point in the analysis of text works:

- the processes of text generation are intentional: text manifests specific pragmatic goals of the author associated with influencing the respondent;

- at the moment of creating the text, the speaker activates specific cognitive knowledge structures such as memory, discursive skills and abilities;

- the act of generating the text creates the unique configuration of cognitive knowledge elements and structures that contribute to the implementation of the author's goals; 
- when analyzing the blog text, stable interdependencies of parts from the aggregate whole and the aggregate whole from the parts that form it are revealed. The text is structured based on the relationships that are relevant between the part and the aggregate whole;

- the blog text is the result of an optimal choice of lexical and grammatical means that can function as the formal indicators of text cohesion and coherence;

- in the process of interpreting the blog texts, the respondent focuses on the type of relationship that is found between the joined text segments.

The manifestation of certain rhetorical relations between blog text segments sheds light on the current intentions of the addressee, which, however, taken by themselves, do not determine these relations. Textual manifestations of rhetorical relations are mainly marked by lexical and grammatical means, but these relations are shown even without explicit marking. As a result, the problem of whether rhetorical relations are actually a product of the interlocutors' cognitive consciousness or whether they appear as a projection of the analysis of researchers of text is solved.

Rhetorical relations reflect the desired goals and results of the interlocutors' phatic contact. As a result, individual segments of the blog text can be viewed in terms of such concepts as identities and differences, agreement and disagreement. The actual agreement/disagreement with the interlocutor's opinion is recorded in the reacting messages of the blog text, since any reaction to one degree or another manifests the agreement or disagreement of the participants in the virtual communication with each other. All other variants of response speech actions, relatively speaking, are located between these two poles, at the points of approximation either to agreement or to disagreement with the previously expressed position.

\section{References}

Akay, O.M., Kalashnikova, A.A., Kalashnikov, I.A., \& Pshenichnaya, A.Yu. (2017). Pragmatic level of language personality in social networks. Current Issues of Linguistics and Didactics: An Interdisciplinary Approach in Humanities (CILDIAH 2017): Proceedings of the 7th International and Practical Conference. Volgograd, Atlantis Press Publ.

Anufrieva, N.A. (2016). The blogosphere as a public information space: The experience of classification. Volga Region Pedagogical Search, 1(15), 81-84. (In Russ.)

Borisova, A.V., \& Semelet, T.A. (2017). Blogosphere and mass media in Runet: The problem of determining the status. Media Research, (4-2), 109-116. (In Russ.)

Gavrilova, G.F. (2015). Sentence and text: Consistency and functionality. Rostov-on-Don, AcademLit Publ. (In Russ.)

Gurochkina, A.G. (2015). Some unsolved problems of computer-mediated communication. Cognitive Studies of Language, 21, 552-554. (In Russ.)

Ibraeva, A.F. (2018). Language features of texts in the English-language and Russian-language blogosphere. Philological Science. Questions of Theory and Practice, 8-2(86), 333-336. (In Russ.)

Kalashnikova, A.A., Akay, O.M., Tsarevskaya, I.V., Volodina, M.S., \& Tsybenko, E.O. (2017). Pragmatic role of a diminutive in computer-mediated communication of social networks. Man in India, 97(16), 161-172.

Kalashnikova, A.A. (2017). Language personality in computer-mediated communication: Questions of theory and pragmatics. Rostov-on-Don, Don State Technical University Publ. (In Russ.)

Kirillov, A.G. (2017). The transformation of the genre of the blog in the programs for instant messaging. Speech Genres, 2(16), 260-267. (In Russ.) 
Kovtunenko, I.V., Bylkova, S.V., Kudryashov, I.A., \& Korman, E.A. (2021). Scenarios for unison text unfolding in Russian blogosphere. Nauchnyi Dialog, (2), 79-94. (In Russ.)

Kudryashov, I.A., \& Kalashnikova, A.A. (2015). Blog as a sphere of implementation of socio-cultural stereotypes. Actual Problems of Philology and Pedagogical Linguistics, XVIII, 40-48. (In Russ.)

Mann, W.C., Matthiessen, Ch.M.I.M., \& Thompson, S.A. (1992). Rhetorical structure theory and text analysis. Discourse Description: Diverse Linguistic Analyses of a FundRaising Text. Amsterdam; Philadelphia: John Benjamins.

Myers, G. (2010). The discourse of blogs and wikis. London, Continuum.

Nayar, P.K. (2010). An introduction to new media and cybercultures. Chichester, Wiley-Blackwell.

Schipichina, L.Yu (2010). Computer-mediated communication. Linguistic aspect. Moscow, Krasnadar. (In Russ.)

Schmidt, J. (2007). Blogging practices. An analytical framework. Journal of ComputerMediated Communication, 12(4), 12-23.

Volodina, M.S., \& Kovalchuk, N.V. (2019). The problem of voice representation in the blog text: Frames, means of expression, intersubjectivity. Baltic Humanitarian Journal, 81(26), 39-42. (In Russ.)

\title{
Bio notes:
}

Viktor M. Shaklein, Doctor of Philology, Professor, Head of the Department of Russian Language and Methods of Teaching of the Peoples' Friendship University of Russia (RUDN University). Research interests: methodology of teaching Russian as a foreign language, culture of Russian speech, applied cultural linguistics. The author of more than 300 scientific publications. E-mail: vmshaklein@bk.ru

Inna V. Kovtunenko, Candidate of Philology, Associate Professor of the Department of Documentation and Language Communication, Head of the Local Centre of Testing in Russian as a Foreign Language of the Don State Technical University. Research interests: computer-mediated communication, methodology of teaching Russian as a foreign language, culture of Russian speech, applied cultural linguistics. The author of more than 50 scientific publications. E-mail: ivkovtunenko@yandex.ru

\section{Модели риторических отношений в русскоязычных блоговых текстах как показатель информационного поведения собеседников}

\author{
В.М. Шаклеин ${ }^{1 凶}$, И.В. Ковтуненко ${ }^{2}$ \\ ${ }^{1}$ Российский университет дружбь народов, \\ Российская Федераџия, 117198, Москва, ул. Миклухо-Маклая, д. 6 \\ ${ }^{2}$ Донской государственный технический университет, \\ Российская Федерация, 344000, Ростов-на-Дону, пл. Гагарина, д. 1 \\ $\square$ vmshaklein@bk.ru
}

Аннотация. Тексты русскоязычных блогов характеризуются тем, что респондент высказывает свое мнение с целью убедить блогера или иного собеседника в эффективности тех или иных идей, охватывающих его личную жизнь и профессиональную деятельность. Респондент приводит аргументы в пользу своего мнения, вводит его обоснование и в то же 
время указывает, что ранее высказанная блогером точка зрения также актуальна в контексте обсуждаемой ситуации. Риторические отношения проецируют бесконфликтное развитие непринужденной коммуникации. В результате точки зрения, выдвинутые блогером и респондентом, дополняют друг друга. Оказывается, одна и та же ситуация потенциально порождает как положительные, так и отрицательные эмоции, и это подчеркивается в виртуальной коммуникации, основанной на реализации фатической функции языка. Риторические отношения внутри текста блога помогают сочетать различные эпистемические позиции, выражаемые собеседниками. В связи с этим актуальной проблемой лингвистического исследования текстов русскоязычных блогов является определение того, образуют ли собеседники, обменивающиеся мнениями и оценками, целостные модели диалогической коммуникации, на основе которых связываются средства связывания стимулирующих и реагирующих сообщений. Эта проблема еще не получила должного эмпирического анализа в русистике и общей теории языка, хотя ее решение, как мы полагаем, содержит существенные последствия для детализации прагматической специфики блоговой коммуникации. Целью исследования является реализация структурно-прагматического анализа риторической предопределенности блоговых текстов. Подобный ракурс изучения предполагает системное описание частотных показателей данного типа отношений с опорой на вариативное моделирование. Поставленная в статье цель достигается посредством использования таких методов исследования, как: 1) наблюдение и интерпретация блоговых текстов в терминах специфических средств манифестации связности; 2) фокус внимания на контекстуальном факторе: непосредственный анализ фрагментов текста блога как линейной последовательности, разворачиваемой во времени; 3) моделирование риторической взаимосвязи между составными компонентами целостных реплик и на уровне целостных диалогических единств в тексте блога. Делается вывод о том, что риторические отношения многомерно отражают национально-культурные стереотипы коммуникации, предопределяют материально выражаемую и мыслимую (идеальную) сферы собеседников, фиксируют палитру оценочного реагирования респондентов. В ходе разворачивания подобных дискурсивных действий участники общения не только прибегают к значимым общекультурным сценариям аксиологической активности, но и детализуют стереотипы такой деятельности, которые задаются системой русского языка. Риторические отношения между стимулирующими и реагирующими сообщениями в контексте компьютерно-опосредованной коммуникации способствуют процессам декодирования информативного и эмоционального содержания совместно генерируемого текста и его импликаций.

Ключевые слова: контекст русскоязычной компьютерно-опосредованной коммуникации, текст русскоязычного блога, риторические отношения, точка зрения собеседника, дискурсивный шаг, интерактивность

История статьи: поступила в редакцию 12.10.2020; принята к печати 22.12.2020.

Для цитирования: Shaklein V.M., Kovtunenko I.V. Models of rhetorical relations in Russian blogging as an indicator of interlocutors' information behavior // Русистика. 2021. T. 19. № 2. C. 167-179. http://dx.doi.org/10.22363/2618-8163-2021-19-2-167-179

\section{Сведения об авторах:}

Шаклеин Виктор Михайлович, доктор филологических наук, профессор, заведующий кафедрой русского языка и методики его преподавания Российского университета дружбы народов. Сфера научных интересов: методика преподавания русского языка как иностранного, культура русской речи, лингвокультурология. Автор более 300 научных публикаций. E-mail: vmshaklein@bk.ru

Ковтуненко Инна Викторовна, кандидат филологических наук, доцент, руководитель Локального центра тестирования по русскому языку как иностранному Донского государственного технического университета. Сфера научных интересов: компьютерно-опосредованная коммуникация, методика преподавания русского языка как иностранного, культура русской речи, лингвокультурология. Автор более 50 научных публикаций. E-mail: ivkovtunenko@yandex.ru 